\title{
O Supremo Tribunal Federal, a presunção de inocência e o direito a uma resposta constitucionalmente adequada
}

\author{
The Supreme Federal Court, the presumption \\ of innocence and the right to a constitutionally \\ adequate response
}

Julio Cesar Muniz Faculdade de Direito do Sul de Minas

Cláudia Mansani Queda de Toledo Faculdade de Direito do Sul de Minas

Resumo O presente artigo aborda a questão da mitigação do princípio da presunção de inocência em recente entendimento do Supremo Tribunal Federal, examinando de forma sistematizada se a Suprema Corte conferiu a melhor interpretação ao disposto no artigo $5^{\circ}$., LVIII, da Constituição da República. Além disso, discorre a respeito dos fundamentos da teoria da decisão judicial formulada por Lenio Luiz Streck e a partir dos parâmetros princípio lógicos dessa teoria coteja o atual posicionamento do Supremo Tribunal Federal sobre a presunção de inocência. Diante de tal contexto, objetiva este trabalho analisar o novo entendimento do Supremo Tribunal Federal acerca da presunção de inocência, tendo como supedâneo a teoria da decisão judicial de Lenio Streck, concluindo que o posicionamento da Suprema Corte não passa pelo filtro hermenêutico da referida teoria da decisão, na medida em que não oferece uma resposta constitucionalmente adequada, principalmente por não respeitar a legislação de estatura constitucional produzida de forma democrática. 
A abordagem do tema é feita por intermédio do método dedutivo, uma vez que parte do conceito e abrangência do princípio constitucional da presunção de inocência e da teoria da decisão judicial formulada por Lenio Luiz Streck, firmando, assim, algumas premissas, para, em seguida, estabelecer-se uma relação entre tal princípio e o novo entendimento a ele conferido pelo Supremo Tribunal Federal, à luz da citada teoria. Palavras-chave: Supremo Tribunal Federal. Presunção de inocÊnCIA. TeOria da Decisão Judicial.

Abstract This article deals with the question of mitigating the principle of presumption of innocence in a recent understanding of the Federal Supreme Court, systematically examining whether the Supreme Court granted the best interpretation to the provisions of art. 5, LVIII, of the Constitution of the Republic. In addition, he discusses the fundamentals of the theory of judicial decision formulated by Lenio Luiz Streck and from the principles of this theory, the current position of the Supreme Court on the presumption of innocence. In view of such an objective context, this work analyzes the new understanding of the Federal Supreme Court regarding the presumption of innocence, having as a footnote Lenio Streck's theory of judicial decision, concluding that the Supreme Court's position does not pass through the hermeneutic filter of said theory of decision, inasmuch as it does not offer a constitutionally adequate response, mainly because it does not respect the legislation of constitutional stature produced democratically. The approach of the topic is made through the deductive method, since it starts from the concept and comprehensiveness of the constitutional principle of the presumption of innocence and the theory of the judicial decision formulated by Lenio Luiz Streck, thus establishing some premises, to establish a relationship between this principle and the new understanding given to it by the Federal Supreme Court in the light of the aforementioned theory.

Key-words: Federal Supreme Court. Presumption of innocence. TheORY OF Judicial DeCISION. 


\section{INTRODUÇÃo}

O tema escolhido versa a respeito da relação entre "o Supremo Tribunal Federal, o princípio da presunção de inocência e o direito a uma resposta constitucionalmente adequada" a partir de uma leitura sistematizada da teoria da decisão judicial formulada pelo jurista Lenio Luiz Streck.

A reflexão sobre o tema suscitado assume contornos importantes no cenário jurídico atual, na medida em que o recente posicionamento do Supremo Tribunal Federal, entendendo que o artigo $5^{\circ}$., inciso LVII, da Constituição da República não impede o início da execução da pena após condenação em segunda instância, ou seja, permite a antecipação da execução da pena, mesmo antes do trânsito em julgado da sentença condenatória, reaviva a importância da análise do mandamento constitucional relativo ao princípio da presunção de inocência e as decisões casuísticas do Poder Judiciário.

Assim, a questão a ser examinada é se o Supremo Tribunal Federal ao mitigar o princípio da presunção de inocência, confere a melhor interpretação ao texto da Constituição da República e formula decisão judicial constitucionalmente adequada ou, ao contrário, faz uso da razão prática, do solipsismo e da discricionariedade judicial.

$\mathrm{O}$ artigo, portanto, tem por objetivo principal analisar o novo entendimento do Supremo Tribunal Federal a respeito da presunção de inocência a partir do filtro hermenêutico da teoria da decisão judicial proposta pelo jurista Lenio Luiz Streck, um dos maiores expoentes da hermenêutica filosófica no Brasil.

Nessa perspectiva, buscou-se, inicialmente, analisar os fundamentos históricos e teóricos do princípio da presunção de inocência, assim como analisar as balizas teóricas que embasam a teoria da decisão judicial de Lenio Luiz Streck para, em seguida, cotejar o novel posicionamento do Supremo Tribunal Federal sobre o princípio da presunção de inocência e o direito fundamental a uma resposta constitucionalmente adequada, utilizando o conjunto de princípios conformadores de um agir concretizador da Constituição propostos por Streck. 
A abordagem do tema é feita por meio do método dedutivo, uma vez que parte do conceito e abrangência do princípio constitucional da presunção de inocência e da teoria da decisão judicial formulada por Lenio Luiz Streck, firmando, assim, algumas premissas, para, em seguida, estabelecer-se uma relação entre tal princípio e o novo entendimento a ele conferido pelo Supremo Tribunal Federal, à luz da citada teoria, de modo que se possa chegar a uma conclusão.

Marconi e Lakatos (2000, p. 69) observam que "no modelo dedutivo, a necessidade de explicação não reside nas premissas, mas, ao contrário, na relação entre as premissas e a conclusão (que acarretam)"'.

Conforme já dito, é justamente o que o presente trabalho propõe: estabelecer premissas sobre o princípio da presunção de inocência e também a respeito da teoria da decisão judicial de Lenio Luiz Streck, de modo a permitir o cotejo do novel entendimento conferido ao mencionado princípio pelo Supremo Tribunal Federal com a teoria da decisão judicial, permitindo-se, assim, a formulação de uma conclusão que seja resultado da relação entre as premissas e a conclusão a que chegamos.

\section{O PRINCÍPIO DA PRESUNÇÃO DE INOCÊNCIA}

Ao abordarmos acerca do princípio da presunção de inocência, importa, inicialmente, a realização de uma digressão histórica para a compreensão da evolução desse instituto e da sua relevância, sobretudo, no que diz respeito à preservação do direito à liberdade.

Foi no contexto das arbitrariedades praticadas no Antigo Regime europeu que emergiu de forma mais consistente o princípio da presunção de inocência a partir da formulação crítica dos pensadores iluministas a respeito dos sistemas penais, resultando na sua inserção na Declaração dos Direitos do Homem e do Cidadão de 1789 (GIACOMOLLI, 2013, p. 441).

De fato, o artigo $9^{\circ}$. da Declaração de Direitos do Homem e do Cidadão de 1789 assim se expressou: "Todo acusado é considerado inocente até ser declarado culpado e, se julgar indispensável prendê-lo, 
todo rigor desnecessário à guarda da sua pessoa deverá ser severamente reprimido pela lei”.

Tal disposição inverteu a lógica até então existente no Antigo Regime e explicitou o princípio da presunção de inocência, ao enunciar que todo acusado é considerado inocente até ser declarado culpado.

No pós Segunda Guerra Mundial, a Declaração Universal dos Direitos Humanos de 1948 também destacou o princípio da presunção de inocência, ao prever no artigo 11:

Todo ser humano acusado de um ato delituoso tem o direito de ser presumido inocente até que a sua culpabilidade tenha sido provada de acordo com a lei, em julgamento público no qual lhe tenham sido asseguradas todas as garantias necessárias à sua defesa.

Outro importante documento internacional, a Convenção Europeia para a Tutela dos Direitos do Homem e da Liberdade Fundamental, firmada em Roma, em 4 de novembro de 1950, reconhece na presunção de inocência um princípio basilar de construção e de desenvolvimento das garantias processuais (GIACOMOLLI, 2013, p. 441).

A Convenção Americana sobre os Direitos Humanos celebrada em São José da Costa Rica, em 22 de novembro de 1969 - referência para a proteção e garantia dos Direitos Humanos - também fez previsão em seu artigo 8.2, afirmando que "Toda pessoa acusada de delito tem direito a que se presuma sua inocência enquanto não se comprove legalmente sua culpa (...)", consagrando de forma expressa o princípio da presunção de inocência.

A previsão do princípio da presunção de inocência nos citados documentos internacionais conduz a uma indissociável relação entre esse princípio e os Direitos Humanos, ou seja, a presunção de inocência é um elemento fundamental de garantia dos Direitos Humanos, na medida em que opõe em relação ao Estado, que detém o monopólio da sanção, o direito do acusado de se defender por todos os meios legais e legítimos que estão colocados à sua disposição pela ordem jurídica. 
No Brasil, a discussão em torno da presunção de inocência se deu, principalmente, em razão da Declaração Universal dos Direitos Humanos. O princípio da presunção de inocência, enquanto postulado universal de direito, referido na Declaração Universal de Direitos Humanos, de 10 de dezembro de 1948, teria sido incorporado à ordem constitucional brasileira por meio da cláusula constante do artigo 153, parágrafo 36, da Constituição de 1967 (MENDES, 2007, p. 594).

Entretanto, a consagração do princípio da presunção de inocência veio na Constituição de 1988, no artigo $5^{\circ}$., inciso LVII, quando determinou, de modo expresso, que "ninguém será considerado culpado até o trânsito em julgado da sentença penal condenatória", cuja redação foi inspirada na Constituição Italiana de 1948 (GIACOMOLLI, 2013, p. 442).

O princípio da presunção de inocência previsto no artigo $5^{\circ}$., inciso LVII, da CR/88, traduz-se na garantia constitucional de não culpabilidade, vedando-se qualquer forma de prejulgamento por parte do aparato estatal e da própria sociedade, bem como, dos órgãos do Poder Judiciário (FERNANDES, 2012, p. 437/438).

Esse princípio tem fundamento na máxima de que ninguém será considerado culpado até que se prove o contrário (ARAÚJO, 2008, p. 135).

Para André Ramos Tavares (2013, p. 577), trata-se de um princípio penal o de que ninguém pode ser tido por culpado pela prática de qualquer ilícito senão após ter sido como tal julgado pelo juiz natural, com ampla oportunidade de defesa.

Não há como olvidar que se cuida de princípio intimamente relacionado ao Estado Democrático de Direito e à necessidade de se garantir ao acusado meios amplos de defesa, de modo a não haver uma antecipação da culpa e não regredir às arbitrariedades praticadas pelo Estado (TAVARES, 2013, p. 577). Vale dizer, a presunção de inocência deve impedir o cerceamento de bem de grande relevância, fundamental na democracia, que é a liberdade.

Nessa perspectiva, a presunção de inocência relaciona-se com os valores da dignidade e dos direitos essenciais da pessoa humana, conforme leciona Nereu José Giacomolli (2013, p. 442): 
A presunção de inocência é um princípio de elevado potencial político e jurídico, indicativo de um modelo basilar e ideológico de processo penal. Este, quando estruturado, interpretado e aplicado, há de seguir o signo da dignidade e dos direitos essenciais da pessoa humana, afastando-se das bases inquisitoriais, as quais partiam do pressuposto contrário, ou seja, da presunção da culpabilidade da pessoa.

O Supremo Tribunal Federal (BRASIL, 2008), em decisão prolatada na ADPF n. 144, afirmou que o princípio da presunção de inocência é um valor fundamental, um "verdadeiro 'cornerstone' em que se estrutura o sistema que a nossa carta política consagra em respeito ao regime das liberdades e em defesa da própria preservação da ordem democrática".

Odoné Sanguiné, citado por Gilmar Mendes, vai acentuar com propriedade a ideia de que não é admissível que a prisão provisória seja adotada com a finalidade de antecipação da pena.

Verificar a base da ratio em que a restrição da liberdade pessoal do imputado pode conciliar-se com o princípio da presunção da inocência, que exclui qualquer identificação entre imputado e culpável antes da sentença de condenação definitiva. Mas afirmada a compatibilidade entre a prisão provisória e a presunção de inocência, não se pode perder de vista aquele direito fundamental, que sempre resultará vulnerado quando a medida de privação de liberdade não responder a exigências cautelares, convertendo-se em pena antecipada (MENDES, 2007, p. 599).

O direito fundamental à presunção de inocência deve impor limites indiscutíveis à adoção da prisão cautelar.

Não se pode conceber como compatível com o princípio constitucional da presunção de inocência qualquer antecipação de cumprimento de pena. Aplicação de sanção antecipada não se compadece com 
a ausência de decisão condenatória transitada em julgado (MENDES, 2007, p. 601).

Isso significa dizer que a regra é a manutenção da liberdade do cidadão. A prisão somente se justifica após uma sentença condenatória com trânsito em julgado (GIACOMOLLI, p. 442).

Ao tratar do tema da prisão provisória e da presunção de inocência, o Prof. Luigi Ferrajoli (2002, p. 446) foi enfático:

[...] a mesma admissão em princípio da prisão ante iudicium, qualquer que seja o fim que se lhe queira associar, contradiz na raiz o princípio da submissão à jurisdição, que não consiste na possibilidade de detenção apenas por ordem de um juiz, mas na possibilidade de sê-lo só com base em um julgamento. Além disso, toda prisão sem julgamento ofende o sentimento comum de justiça, sendo entendido como um ato de força e de arbítrio. Não há de fato qualquer provimento judicial e mesmo qualquer ato dos poderes públicos que desperte tanto medo e insegurança e solape a confiança no direito quanto o encarceramento de um cidadão, às vezes por anos, sem processo.

O exame da gênese do instituto da presunção de inocência, sua inserção no texto da Constituição da República e as balizas que compõem o Estado Democrático de Direito dão sentido ao valor desse princípio como suporte na preservação da liberdade, na medida em que a prisão provisória deve se apresentar como excepcionalidade e não como sinal de abuso e arbitrariedade do Estado e no desejo de antecipação da pena antes mesmo do trânsito em julgado da decisão condenatória.

Nesse sentido, ao se conceber de outra forma, em nome de casuísmos ou de circunstancialismos políticos e sociais, ocorre uma interpretação equivocada e esvaziada do texto da Constituição da República, que na sua essência dispõe que as restrições somente se justificam após o trânsito em julgado de uma sentença penal condenatória (GIACOMOLLI, 2013, p. 444). 
Não se pode perder de vista, também, que a própria legislação infraconstitucional, com esteio no que prevê a Constituição, assegura que a prisão com finalidade punitiva (prisão pena, e não prisão cautela), somente deve ocorrer após o trânsito em julgado.

É o que se vê, por exemplo, da redação do artigo 283 do Código de Processo Penal, quando assegura que "ninguém poderá ser preso senão em flagrante delito ou por ordem escrita e fundamentada da autoridade judiciária competente, em decorrência de sentença condenatória transitada em julgado ou, no curso da investigação ou do processo, em virtude de prisão temporária ou prisão preventiva".

Há, portanto, de acordo com esse dispositivo legal, três espécies de prisão: a) prisão em flagrante delito, nos casos em que a lei considera haver estado flagrancial; b) a prisão pena, que pressupõe sentença condenatória transitada em julgado (exigência esta, ademais, contida na própria Constituição); e c) a prisão cautelar, seja ela temporária ou preventiva, que pode ser decretada na presença de seus requisitos legais.

A única espécie de prisão que dispensa, para a sua concretização, de decisão fundamentada de autoridade judiciária competente, é a prisão em flagrante, muito embora após as alterações promovidas pela Lei n. 12.403 , de 4 de maio de 2011, também essa deverá ser comunicada ao juiz competente, a quem cabe decidir, fundamentadamente, pelo relaxamento da prisão, se a considerar ilegal, por sua conversão em prisão preventiva, se preenchidos os requisitos legais, ou pela concessão de liberdade provisória, com ou sem fiança (CPP, artigos 306 e 310).

Após esses apontamentos acerca das características do princípio constitucional da presunção de inocência e da forma como se encontra positivado na Constituição brasileira, passemos, agora, à análise da teoria da decisão judicial formulada pelo jurista Lenio Luiz Streck.

\section{A teoria da decisão Judicial de Lenio Luiz Streck}

Para possibilitar a análise do novel entendimento conferido pelo Supremo Tribunal Federal ao princípio da presunção de inocência com 
a teoria da decisão judicial proposta por Lenio Luiz Streck, é preciso dedicar algumas linhas deste trabalho para se traçar um panorama com os pontos centrais do pensamento do jurista gaúcho.

A opção por se adotar a teoria formulada por Lenio Luiz Streck para a análise proposta deve-se à sobriedade de seus argumentos na busca de critérios que permitam contingenciar a prevalência da razão prática, o solipsismo do julgador, a discricionariedade judicial, em detrimento das fontes democráticas do direito, preservando, assim, sua autonomia.

A preocupação de Streck com a formulação de uma teoria da decisão judicial surge com a constatação da ausência de uma teoria do direito que se preocupe com o ato decisório, seja dos juízes ou dos tribunais, uma vez que não se pode admitir, no atual estágio evolutivo do Estado Democrático de Direito, que a decisão judicial seja um ato de escolha individual do julgador, já que isso compromete o ponto central do constitucionalismo contemporâneo, que é a democracia. Não é admissível a substituição do juiz "boca da lei" pelo juiz que é o "proprietário do sentidos da lei” (STRECK, 2014a, p. 598).

O que sempre pretendi dizer é que não teria sentido que, nesta quadra da história, depois da superação dos autoritarismos/totalitarismos surgidos no século XX e no momento em que alcançamos esse (elevado) patamar de discussão democrática dos direitos, viéssemos a 'depender' da discricionariedade dos juízes na discussão dos assim chamados 'casos difíceis' ou em face das (inexoráveis) incertezas da linguagem. Ora, pensar assim seria substituir a democracia pela 'vontade de poder' (entendido como o último princípio epocal da modernidade) dos juízes ou de uma doutrina que, seguida pelos juízes, substituísse a produção democrática do direito. Essa produção democrática do direito - plus normativo/qualitativo que caracteriza do Estado Democrático de Direito - é um salto para além do paradigma subjetivista (STRECK, 2014a, p. 493). 
A discricionariedade foi um dos marcos do positivismo e a superação deste requer que se supere aquela, afastando, nas palavras de Streck (2014a, p. 515), o "solipsismo da razão prática".

A busca da superação do solipsismo judiciário não pode, entretanto, ser compreendida como uma proibição de se interpretar ou como uma pretensão de se apequenar o Poder Judiciário. Trata-se, ao contrário, de reconhecer o papel estratégico ocupado pelo Judiciário nas democracias constitucionais contemporâneas, notadamente para a concretização dos direitos fundamentais, o que pressupõe a necessidade de se estabelecer elementos hermenêuticos capazes de conferir legitimidade às decisões judiciais, possibilitando, assim, "aos participantes da comunidade política meios para questionar a motivação das decisões de modo a gerar, nessas mesmas motivações, um grau muito mais elevado de legitimidade" (STRECK, 2014b, p. 329).

Há o dever de se respeitar a legislação produzida de forma democrática, o que significa aquela cujo sentido foi filtrado princípio logicamente, pois não se pode admitir que posicionamentos particulares dos julgadores, derivados de convicções políticas, possam ter um valor mais elevado do que as próprias leis (em sentido amplo), que também devem passar pelo controle de compatibilidade com os princípios constitucionais. Não pode, de modo algum, "haver decisão judicial que não seja fundamentada e justificada em um todo coerente de princípios que repercutam a história institucional do direito" (STRECK, 2014a, p. 518-519).

O pós-positivismo, o constitucionalismo contemporâneo e a democracia implicam que se reconheça a autonomia do direito, o que pressupõe que questões de natureza política e moral sejam debatidas à exaustão quando da produção do direito, nos meios políticos de decisão, e não no ato decisório, cuja desconsideração das escolhas realizadas no âmbito político democraticamente, só pode se justificar se estiver em desacordo com o que preceitua a Constituição (STRECK, 2014a, p. 523). Do contrário, é preciso que se preserve o direito e sua autonomia.

Lenio Streck (2014b, p. 330), na esteira das formulações feitas por Gadamer em Verdade e Método, busca a reabilitação da autorida- 
de da tradição e concomitantemente reconhece que a possibilidade de compreensão está nos pré-juízos, que possibilitam a compreensão, por projetarem sentido. O sentido projetado, porém, só pode ser confirmado se tiver por fundamento um pré-juízo que seja legítimo (STRECK, 2014b, p. 330).

Pré-juizos ilegítimos geram projetos de sentido ilegítimos e, inevitavelmente, fazem a interpretação incorrer em erros. Apenas quem suspende os próprios pré-juízos é que interpreta corretamente. Um julgador que não consegue suspender seus pré-juízos está incapacitado para sua tarefa (STRECK, 2014b, p. 330-331).

Afastando-se, assim, de seus pré-juízos ilegítimos, o que torna uma decisão legítima é a demonstração de que a norma por ela produzida tem por fundamento um princípio, fruto da tradição, pois não existe regra sem um princípio que a tenha instituído, já que isso implicaria a inaplicabilidade da norma por ausência de legitimidade democrática (STRECK, 2014a, p. 553).

Regras e princípios, que constituem o todo o direito, foram criados exatamente para, mediante um processo interpretativo, guiarem a aplicação do direito e trazerem, em certo sentido, segurança jurídica (não entendida como previsibilidade, mas o respeito à coerência e à integridade) (STRECK, 2014a, p. 599).

No âmago de sua Teoria da Decisão Judicial, Streck (2014a, p. 600-601) propõe um conjunto mínimo de quatro princípios "conformadores de um agir concretizador da Constituição", que passamos a analisar a seguir.

\subsection{Primeiro princípio: preservar a autonomia do direito}

A autonomia do direito surgiu no contexto histórico do século XX e alcançou seu apogeu com a elaboração das Constituições posteriores à Segunda Guerra Mundial. A autonomia do direito significa que ele deve 
ser compreendido em seu aspecto autônomo em relação a outras dimensões que com ele se relacionam de modo recíproco, como a política, a economia e a moral (STRECK, 2014a, p. 601), evitando-se assim que haja uma contaminação do direito, por tais dimensões, no ato decisório. Simioni (2014, p. 775) observa que:

[...] um direito sem autonomia perde uma das mais importantes conquistas civilizatórias da sociedade, que é a possibilidade dele se constituir como uma regra contramajoritária, quer dizer, a possibilidade do direito constituir-se na experiência política como um critério importante para se opor inclusive às opiniões das maiorias democráticas. E não é só: um direito sem autonomia não é mais direito, pois aí já não haveria mais nenhuma diferença entre critérios jurídicos para solução e problemas concretos e os demais critérios políticos, econômicos, organizacionais etc. Um direito sem autonomia não é mais que um instrumento ou um programa estratégico carente de critérios para julgar a validade, a legitimidade e a correção - ou justiça, se assim se quiser - das nossas práticas sociais.

Como já visto, questões políticas e morais devem ser debatidas no âmbito de produção democrática do direito, não podendo, em respeito à sua autonomia, que sejam invocadas como fundamento decisório em detrimento do direito produzido democraticamente.

A preservação da autonomia do direito implica, também, o reconhecimento e aplicação dos diversos padrões interpretativos que são trabalhados pelo direito constitucional, designados de métodos ou princípios, entre os quais destacam-se o da correção funcional, segundo o qual a instância decisória não pode modificar a distribuição das funções e competências normatizadas pela Constituição, seja no modo de decidir seja em razão do resultado desta; o respeito à rigidez do texto constitucional, que cria uma barreira protetora para o direito contra "as convicções revolucionárias acerca da infalibilidade do legislador”; a preservação da força normativa da Constituição e da máxima efetivi- 
dade, que fazem que a Constituição seja interpretada de modo a lhe assegurar a maior eficácia (STRECK, 2014a, p. 601).

Não se pode descurar, também, dos limites semânticos impostos pela Constituição, devendo seu texto ser levado a sério. Streck (2014a, p. 601) enfatiza que:

[...] é evidente que o texto não se basta; é evidente que texto e norma não são a mesma coisa; mas o texto já fala de alguma coisa, sobre alguma coisa e alguma coisa, assumindo relevância a tese da 'legalidade constitucional' de Elías Díaz, assim compreendido como "o conjunto de operações do Estado que é determinado não apenas pela lei, mas também pela Constituição [...] e pela efetividade das decisões judiciais sob o marco de uma legitimidade democrática” (STRECK, 2014a, p. 602).

Desse modo, a preservação da autonomia do direito pressupõe que o Poder Judiciário somente deixe de aplicar uma lei (em sentido amplo) ou dispositivo legal na ocorrência de uma das seguintes hipóteses: a) quando a lei ou ato normativo for inconstitucional; b) quando for necessária a utilização de critérios de resolução de antinomias, a exemplo do critério de que a lei especial revoga a geral; c) quando lançar mão da interpretação conforme a Constituição; d) quando aplicar a nulidade parcial sem redução de texto; e) quando declarar a inconstitucionalidade com redução de texto; f) quando for o caso de deixar de aplicar uma regra para a prevalência de um princípio (STRECK, 2014a, p. 604-605).

\subsection{Segundo princípio: o controle hermenêutico da in- terpretação constitucional}

Segundo esse princípio, é preciso impor limites às decisões judiciais, evitando-se, assim, o problema da discricionariedade judicial, porquanto a inexistência de um método que assegure a "correção" do processo interpretativo não pode servir de fundamento para que o intérprete adote o sentido que melhor lhe aprouver, "pois se o intérprete 
escolhe os sentidos, a democracia depende do intérprete" (STRECK, 2014a, p. 605-606).

\begin{abstract}
A "vontade" e o "conhecimento" do intérprete não constituem salvo-conduto para a atribuição arbitrária de sentidos e tampouco para uma atribuição de sentidos arbitrária (que é decorrência da discricionariedade). E uma Teoria da Decisão deve assumir esse compromisso de evitar o arbítrio. Não há ad libitum em uma democracia (STRECK, 2014a, p. 606).
\end{abstract}

Com efeito, cabe ao intérprete a atribuição de sentidos possíveis ao texto legal, respeitando-se, sempre, a autonomia do direito, com olhos voltados à comunidade de princípios reconhecidos pela tradição jurídica.

\title{
2.3. Terceiro princípio: $o$ efetivo respeito à integridade e à coerência do direito
}

$\mathrm{O}$ respeito à integridade e à coerência visam criar barreiras efetivas contra a fragmentação do direito, que são características das teorias pragmaticistas. A integridade relaciona-se de modo direto com a democracia, pois exige dos juízes a construção de argumentos que estejam integrados ao conjunto do direito, ao passo que a coerência pressupõe a aplicação dos mesmos princípios utilizados em determinada decisão, para a decisão de casos idênticos (STRECK, 2014a, p. 607-609).

Isso não significa, porém, que integridade seja apenas coerência, no sentido de decidir casos semelhantes de igual forma, haja vista que, por vezes, a integridade exigirá o afastamento "da estreita linha das decisões anteriores, em busca de fidelidade aos princípios mais fundamentais da comunidade política como um todo", permitindo e incentivando o juiz, assim, "a ser mais abrangente e imaginativo em sua busca de coerência com o princípio fundamental" (STRECK, 2014a, p. 609-610).

Fica claro, portanto, que tanto a integridade quanto a coerência devem ser analisadas de modo amplo, em sua correlação com os princípios fundamentais que orientam o ordenamento jurídico como um todo, 
admitindo-se, assim, o desrespeito aos precedentes jurisprudenciais se - e somente se - tal atitude for necessária para a preservação da integridade do direito e para direcioná-lo a uma situação de coerência com os princípios fundamentais.

\subsection{Quarto princípio: o dever fundamental de justificar as decisões ou como a motivação não é igual à justificação}

$\mathrm{O}$ dever de fundamentar as decisões encontra-se previsto no artigo 93, inciso IX, da Constituição da República.

Streck (2014a, p. 612-614) observa que "no Estado Democrático de Direito, mais do que fundamentar uma decisão, é necessário justificar (explicitar) o que foi fundamentado". Ao mesmo tempo, salienta que a fundamentação é algo que vai muito além de uma exposição de motivos, uma vez que é perfeitamente possível que haja vários motivos para se fazer algo e nenhum deles seja justificado.

A justificação (ou fundamentação) da decisão pressupõe, assim, a sua conformação com a Constituição, com os princípios fundamentais que orientam todo o ordenamento jurídico, para que possa ser preservada a integridade e coerência do direito.

\subsection{Quinto princípio: o direito fundamental a uma resposta constitucionalmente adequada}

Diretamente relacionado com o princípio anterior, o direito fundamental a uma resposta constitucionalmente adequada é uma garantia que assiste a cada cidadão de que sua causa seja julgada a partir da Constituição e que lhe seja possível, a partir da justificação apresentada, aferir se a resposta obtida está ou não em conformidade com a Constituição (STRECK, 2014a, p. 615).

O direito a uma resposta constitucionalmente adequada é, segundo Streck (2014a, p. 617),

[...] consequência da obediência aos demais princípios, isto é, a decisão (resposta) estará adequada na medida em que for respeitada, em maior grau, a autonomia do direito 
(que se pressupõe produzido democraticamente), evitada a discricionariedade (além da abolição de qualquer atitude arbitrária) e respeitada a coerência e a integridade do direito, a partir de uma detalhada fundamentação.

É, assim, da conjugação dos quatro primeiros princípios apontados por Streck que se assegura o direito à decisão constitucionalmente adequada, que se traduz num direito fundamental de todo cidadão que viva sob a égide de um Estado Democrático de Direito.

$\mathrm{O}$ que se pretende, no item seguinte, é justamente analisar o novel entendimento do Supremo Tribunal Federal acerca da presunção de inocência sob o crivo hermenêutico da Teoria da Decisão Jurídica proposta por Lenio Streck, de modo a analisar se esse novo entendimento passa pelo filtro dos cinco princípios já explicitados ou se, ao contrário, a decisão não foi constitucionalmente adequada.

\section{O novel entendimento do Supremo Tribunal Fede- RAL ACERCA DO PRINCÍPIO DA PRESUNÇÃO DE INOCÊNCIA E O DIREITO FUNDAMENTAL A UMA RESPOSTA CONSTITUCIONALMENTE ADEQUADA}

Até o ano de 2008, havia entendimento consolidado no Supremo Tribunal Federal, no sentido de que a execução provisória da pena não violava o princípio constitucional da presunção de inocência, quando pendentes de julgamento apenas recursos de natureza extraordinária.

O habeas corpus $\mathrm{n}^{\circ}$. 71.723/SP bem ilustra a questão, quando se observa da ementa de seu acórdão que havia um entendimento "assentado nesta corte [STF] de que os recursos extraordinário e especial, por não estarem revestidos de efeito suspensivo, não impedem a execução provisória da pena de prisão (BRASIL, 1995)". ${ }^{1}$

1 No mesmo sentido, exemplificativamente, é possível encontrar, ainda, os seguintes julgados, todos do Supremo Tribunal Federal: HC 79.814, publicado no DJ de 13/10/2000; RHC 84.846, publicado no DJ de 05/11/2004; HC 91.675, publicado no DJe de $07 / 12 / 2007$. 
No ano de 2008, uma decisão prolatada pelo Supremo Tribunal Federal, nos autos da ADPF $n^{\circ}$. 144, passou a sinalizar uma mudança de posicionamento da corte no que tange à abrangência da presunção de inocência, quando reconheceu que a existência de procedimentos judiciais de natureza criminal, em que não houvesse sentença condenatória transitada em julgado, não poderia ser causa de inelegibilidade, justamente com fundamento no princípio da presunção de inocência, uma vez que isso implicaria em suspensão dos direitos políticos, o que pressupõe o trânsito em julgado de condenação criminal (BRASIL, 2008).

Foi no ano de 2009, porém, que a guinada interpretativa por parte do Supremo Tribunal Federal ficou evidente, quando o Tribunal Pleno, no julgamento do habeas corpus $\mathrm{n}^{0}$. 84.078-7/MG (BRASIL, 2009), passou a entender não mais ser admissível a execução provisória da pena, ainda quando restassem para ser julgados apenas recurso especial ou extraordinário, em atenção ao princípio da presunção de inocência e também em razão do próprio direito de defesa.

Para o Supremo Tribunal Federal, a ampla defesa não poderia ser visualizada de modo restrito. Deveria, assim, englobar todas as fases recursais, inclusive as de natureza extraordinária, de modo que, se permitir a execução provisória da pena, após o julgamento do recurso de apelação, implicaria, além da já aventada violação ao princípio da presunção de inocência, também "restrição do direito de defesa, caracterizando desequilíbrio entre a pretensão estatal de aplicar a pena e o direito, do acusado, de elidir essa pretensão" (BRASIL, 2009).

Ao longo de mais de sete anos, esse mesmo entendimento continuou a prevalecer no Supremo Tribunal Federal, ${ }^{2}$ até que, em fevereiro de 2009, ao decidir o habeas corpus $\mathrm{n}^{\circ}$. 126.292/SP, a corte mudou seu posicionamento, em decisão tomada pelo Tribunal Pleno, passando a defender que não haveria comprometimento do princípio constitucio-

\footnotetext{
2 A confirmar essa afirmação, confiram-se, a título exemplificativo, os seguintes julgados, todos os Supremo Tribunal Federal: HC 98463, julgado em 15/09/2009; HC 102424, julgado em 14/12/2010; HC 106886, julgado em 15/03/2011; HC 119759, julgado em 18/02/2013; HC 119348, julgado em 18/02/2014; HC 107710 AgR, julgado em 09/06/2015.
} 
nal da presunção de inocência, afirmado pelo artigo $5^{\circ}$., inciso LVII da Constituição da República, em razão da "execução provisória de acórdão penal condenatório proferido em grau de apelação, ainda que sujeito a recurso especial ou extraordinário" (BRASIL, 2016).

$\mathrm{O}$ mesmo entendimento foi reafirmado em outros julgamentos posteriores do Supremo Tribunal Federal, ${ }^{3}$ inclusive com a invocação do disposto no artigo 637 do Código de Processo Penal, segundo o qual, “o recurso extraordinário não tem efeito suspensivo e, uma vez arrazoados pelo recorrido os autos do traslado, os originais baixarão à primeira instância, para a execução da sentença".

O Ministro Luis Edson Fachin chegou a sustentar que, no plano infraconstitucional, os artigos 147 e 164 da Lei de Execução Penal, que poderiam sugerir a necessidade de trânsito em julgado da sentença penal condenatória para que se pudesse iniciar a execução da pena, não prevalecem, uma vez que anteriores à Lei n. 8.038/90, que previu não serem os recursos especial e extraordinário dotados de efeito suspensivo (BRASIL, 2016).

Quanto a esse ponto, há que se relembrar (porque já citado), o disposto no artigo 283 do Código de Processo Penal, com redação dada pela Lei n. 12.403, de 4 de maio de 2011, que exige o trânsito em julgado da sentença condenatória para que se possa recolher alguém à prisão em razão de uma pena imposta em condenação criminal. Sua redação é posterior à entrada em vigor da Lei n. 8.038/90, o que implicaria na sua prevalência sobre esta, além de se tratar de uma norma especial, voltada exclusivamente para o processo penal, o que, contudo, não foi observado pelo Ministro Fachin.

Conjugando-se o disposto no artigo 283 do Código de Processo Penal com os regramentos contidos na Lei n. 8.038/90, o que se conclui é que, nos outros ramos do direito, os recursos especiais e extraordinários não são dotados de efeito suspensivo, o que, contudo, não ocorre no cam-

HC 131547, julgado em 23/02/2016; RHC 133483, julgado em 03/05/2016; HC 133679 AgR, julgado em 03/05/2016; HC 125708 AgR, julgado em 17/05/2016; HC 130709, julgado em 07/06/2016; ARE 737305 AgR, julgado em 28/06/2016. 
po do direito processual penal, à vista da redação do artigo 283 do Código de Processo Penal, já que um dos critérios de resolução de antinomias legislativas determina que a norma especial prevaleça sobre a geral.

O Ministro Luis Roberto Barroso chegou a fazer menção expressa ao artigo 283 do Código de Processo Penal em seu voto (BRASIL, 2016), sustentando que ele não serviria para impedir a prisão posteriormente à condenação em segundo grau, "por fundamento diretamente constitucional. Acentue-se, porque relevante: interpreta-se a legislação ordinária à luz da Constituição, e não o contrário".

O que causa estranheza nessa afirmação é justamente o fato de que o artigo 283 do Código de Processo Penal, em sua atual redação, estar devidamente alinhado ao inciso LVII do artigo $5^{\circ}$. da Constituição Federal, no sentido de que somente seria possível executar uma pena imposta em sentença penal condenatória após o trânsito em julgado desta.

Com essas considerações, passamos à efetiva análise desse novo entendimento do Supremo Tribunal Federal sob o filtro hermenêutico da teoria da decisão judicial formulada por Lenio Luiz Streck, cujos principais contornos foram já apontados. Essa análise será feita mediante respostas a cinco indagações, que correspondem exatamente aos cinco princípios firmados por Streck para que se possa analisar a adequação de uma decisão à Constituição da República.

\subsection{O entendimento do Supremo Tribunal Federal sobre a presunção de inocência preserva a autonomia do direito?}

A preservação da autonomia do direito, como visto, pressupõe que questões políticas e morais sejam debatidas no âmbito de produção democrática do direito, não podendo ser invocadas como fundamento decisório em detrimento do direito produzido democraticamente.

Em diversas passagens dos votos dos ministros que se posicionaram de modo favorável à possibilidade de execução provisória da pena, mesmo que pendentes de julgamento recursos de natureza extraordinária, é possível encontrar fundamentos de ordem política.

O relator do habeas corpus $\mathrm{n}^{\circ}$. 126.292/SP, Ministro Ricardo Levandowisk, observou: 
[...] que o princípio da presunção da inocência - a ponto de negar executividade a qualquer condenação enquanto não esgotado definitivamente o julgamento de todos os recursos, ordinários e extraordinários - tem permitido e incentivado, em boa medida, a indevida e sucessiva interposição de recursos das mais variadas espécies, com indisfarçados propósitos protelatórios visando, não raro, à configuração da prescrição da pretensão punitiva ou executória.

Esses argumentos, com o devido respeito, parecem claramente ter natureza política e não jurídica. Se de fato recursos passaram a ser utilizados com propósito protelatório, apenas visando à extinção da punibilidade, em decorrência da prescrição, é preciso que se reveja a estrutura recursal, tarefa essa que cabe aos legisladores, não sendo admissível, assim, que a pretexto do mau uso dos recursos, se subverta um princípio constitucional de contornos nítidos, como o é o princípio da presunção de inocência.

É do voto do Ministro Luis Roberto Barroso, contudo, que a conotação política da fundamentação fica ainda mais evidente. Muito embora tenha ele apontado diversos fundamentos jurídicos a justificar sua decisão (com os quais respeitosamente não concordamos), chamam a atenção três pontos de destaque em seu voto, quais sejam, o argumento de que a impossibilidade de execução da pena antes do trânsito em julgado da sentença penal condenatória a) teria funcionado "como um poderoso incentivo à infindável interposição de recursos protelatórios"; b) teria reforçado a seletividade do sistema penal, pelo fato de que o direito de recorrer em liberdade aproveitaria "sobretudo aos réus abastados, com condições de contratar os melhores advogados para defendê-los em sucessivos recursos"; e c) o novo entendimento adotado pelo STF a partir de 2009 teria contribuído "significativamente para agravar o descrédito do sistema de justiça penal junto à sociedade" (BRASIL, 2016).

Barroso (BRASIL, 2016), ainda, destacou que, após a condenação em segundo grau, a execução da pena passaria a ser uma exigência de ordem pública, no que foi corroborado pelo Ministro Luis Fux, quando 
argumentou que hoje é inequívoco que a sociedade não aceita mais a liberdade de um condenado que não para de recorrer. ${ }^{4}$

Há nessas passagens evidentes violações à autonomia do direito, porquanto foi utilizado (o direito) com finalidade manifestamente instrumental (afastar a interposição de recursos protelatórios, minimizar a seletividade penal, diminuir o descrédito da justiça penal, garantir a ordem pública e atender aos anseios da sociedade). Simioni (2014, p. 773) bem destaca que:

[...] o direito é muito mais do que um instrumento para a realização de finalidades. $\mathrm{O}$ direito é um critério de justiça que deve poder ser oposto inclusive contra certas finalidades políticas e econômicas. E isso, naturalmente, pressupõe uma concepção de direito não instrumental, não estratégica, mas sim um direito autônomo em relação a exigências sociais e, exatamente por isso, capaz de servir de critério jurídico para decisões sobre o certo e o errado nas estratégias políticas e econômicas do governo ou das organizações ou das pessoas em geral.

Ainda na esteira das proposições formuladas por Streck, há manifesto desrespeito à rigidez do texto constitucional e à força normativa da constituição e da máxima efetividade, que fazem que a Constituição seja interpretada de modo a lhe assegurar a maior eficácia (STRECK, 2014a, p. 601).

O texto do artigo $5^{\circ}$., inciso LVII, não parece permitir outra interpretação senão a de que a presunção de inocência somente deixa de prevalecer após o trânsito em julgado da sentença penal condenatória.

4 Confira-se o excerto do voto do Ministro Luis Fux, quando faz menção a esta questão: "É preciso observar que, quando uma interpretação constitucional não encontra mais ressonância no meio social - e há estudos de Reva Siegel, Robert Post, no sentido de que a sociedade não aceita mais - e se há algo inequívoco hoje, a sociedade não aceita essa presunção de inocência de uma pessoa condenada que não para de recorrer -, com a seguinte disfunção, a prescrição, nesse caso, ela também fica disfuncional, como destacou o eminente Procurador da República, se o réu não é preso após a apelação, porque, depois da sentença ou acórdão condenatório, o próximo marco interruptivo da prescrição é o início do cumprimento da pena" (BRASIL, 2016). 
Se é verdade que o texto não basta por si mesmo e que texto e norma não se confundem (já que a norma é resultado da interpretação do texto), não há como negar a existência de limites semânticos impostos pela Constituição, devendo seu texto ser levado a sério (STRECK, 2014a, p. 601-602).

A preservação da autonomia do direito, como já destacado, pressupõe que o Poder Judiciário somente deixe de aplicar uma lei (em sentido amplo) ou dispositivo legal na ocorrência de uma das seguintes hipóteses: a) quando a lei ou ato normativo for inconstitucional; b) quando for necessária a utilização de critérios de resolução de antinomias, a exemplo do critério de que a lei especial revoga a geral; c) quando lançar mão da interpretação conforme a Constituição; d) quando aplicar a nulidade parcial sem redução de texto; e) quando declarar a inconstitucionalidade com redução de texto; f) quando for o caso de deixar de aplicar uma regra para a prevalência de um princípio (STRECK, 2014a, p. 604-605).

Não houve, no julgamento do habeas corpus 126.292/SP, reconhecimento da inconstitucionalidade do artigo 283 do Código de Processo Penal (até porque dizer isso seria o mesmo que afirmar que o art. $5^{\circ}$., inciso LVII da Constituição é inconstitucional), de modo que, em observância aos critérios de resolução de antinomias legislativas, a lei posterior revoga a anterior (a redação do art. 283 remonta ao ano de 2011, devendo, assim, prevalecer sobre o disposto no art. 637 do mesmo código, que data da década de 1940) e a lei especial prevalece sobre a geral (o disposto no art. 283 da Lei Adjetiva Penal é especial em relação à lei n. 8.038/90, que definiu que os recursos especial e extraordinário não são dotados de efeito suspensivo).

Além disso, numa interpretação do Código de Processo Penal conforme a Constituição, toda e qualquer interpretação que se lhe pretenda dar deve sempre caminhar no sentido de que é inviável a execução de sentença penal condenatória, senão após seu trânsito em julgado.

Não há que se falar, portanto, em declaração de inconstitucionalidade com redução de texto, até porque, para que alguma inconstitucionalidade do artigo 283 do Código de Processo Penal fosse reconhecida 
seria necessária a redução do texto do artigo $5^{\circ}$., inciso LVII da Constituição, o que por óbvio é inadmissível.

Por fim, na hipótese de se deixar de aplicar uma regra para a prevalência do princípio, a regra a ser afastada deve ser a que atribui efeito suspensivo aos recursos especial e extraordinário, devendo assim prevalecer o princípio constitucional da presunção de inocência.

Independentemente do ângulo sob o qual se analisa a questão, resta claro que a decisão do Supremo Tribunal Federal no habeas corpus 126.292/SP e as que seguiram seu entendimento, não preservam a autonomia do direito.

\subsection{O entendimento do Supremo Tribunal Federal sobre a presunção de inocência passa pelo controle hermenêutico da interpretação constitucional?}

De acordo com o princípio do controle hermenêutico da interpretação constitucional, é preciso impor limites às decisões judiciais, evitando-se, assim, o problema da discricionariedade judicial, não sendo possível ao intérprete atribuir ao texto constitucional a interpretação que "achar" mais adequada, não tendo o intérprete, por sua "vontade" e "conhecimento", um salvo-conduto para a atribuição arbitrária de sentidos. Conforme bem sintetiza Streck, "não há ad libitum em uma democracia" (STRECK, 2014a, p. 605- 606).

Não parece depender de muito esforço interpretativo para se concluir que, onde o texto constitucional diz que "ninguém será considerado culpado até o trânsito em julgado de sentença penal condenatória" (CR/88, art. $5^{\circ}$. LVII), é preciso que se reconheça que, antes do trânsito em julgado de sentença penal condenatória ninguém seja considerado culpado. Ao concluir de modo diverso, a decisão do Supremo Tribunal Federal não subsiste num controle hermenêutico da interpretação constitucional. 


\subsection{O entendimento do Supremo Tribunal Federal sobre a presunção de inocência respeita a integridade e a coerência do direito?}

Se considerarmos, como já apontado, que a integridade relaciona-se de modo direto com a democracia, ao exigir dos juízes a construção de argumentos que estejam integrados ao conjunto do direito, ao passo que a coerência pressupõe a aplicação dos mesmos princípios utilizados em determinada decisão, para a decisão de casos idênticos (STRECK, 2014a, p. 607-609), também não há a menor dúvida de que a decisão paradigmática adotada pelo STF no habeas corpus 126.292 /SP fere tanto a integridade quanto a coerência do direito.

Há que se relembrar que integridade não é apenas coerência, no sentido de que casos semelhantes sejam decididos de igual forma, até porque, como já destacado, muitas vezes, a integridade exige o afastamento "da estreita linha das decisões anteriores, em busca de fidelidade aos princípios mais fundamentais da comunidade política como um todo", permitindo e incentivando o juiz, assim, "a ser mais abrangente e imaginativo em sua busca de coerência com o princípio fundamental" (STRECK, 2014a, p. 609-610).

Foi o que aconteceu em 2009, quando do julgamento do habeas corpus 84.078/MG, no qual o Supremo Tribunal Federal, abandonando a linha de precedentes que admitia a execução provisória da pena, vale dizer, que a sentença penal condenatória produzisse seus efeitos mesmo antes do trânsito em julgado, buscou coerência com o princípio fundamental (no caso, da presunção de inocência), modificando corretamente o entendimento que a Corte vinha adotando até então.

$\mathrm{O}$ novo posicionamento do STF no tocante à amplitude do princípio da presunção de inocência, contudo, violou a um só tempo a coerência e a integridade do direito, pois o desrespeito aos precedentes jurisprudenciais somente se mostra admissível quando necessário para se preservar a integridade do direito e para direcioná-lo a uma situação de coerência com os princípios fundamentais, o que, evidentemente, não foi o que se deu com a decisão em análise. 


\subsection{A decisão do Supremo Tribunal Federal sobre a presunção de inocência observou o dever fundamental de justificar as decisões?}

Foram muitos os motivos apontados pelos ministros do Supremo Tribunal Federal para reconhecer que não há incompatibilidade entre o princípio da presunção de inocência, como previsto na Constituição da República, e a execução provisória da pena.

Há que se relembrar, entretanto, que na lição de Streck (2014a, p. 612-614), fundamentar não é o mesmo que apontar motivos, porquanto pode-se ter muitos motivos para adotar uma ou outra decisão, mas nenhum deles ser justificado.

A justificação (ou fundamentação) da decisão pressupõe, conforme já observado, a sua conformação com a Constituição, com os princípios fundamentais que orientam todo o ordenamento jurídico, para que possa ser preservada a integridade e coerência do direito, o que, com o devido respeito daqueles que entendem de modo diverso, não é o caso do novel entendimento do Supremo Tribunal Federal sobre a extensão do princípio da presunção de inocência, já que manifestamente em confronto com a Constituição, que estabeleceu (diga-se pela última vez) um marco claro a partir do qual alguém deixa de ser considerado culpado: o trânsito em julgado da sentença penal condenatória.

Os motivos para a adoção do novo posicionamento do STF podem ser reais e até mesmo relevantes, mas, ao que se pode concluir, nenhum deles se justifica, pelo fato de não estarem conformados com a Lei Maior. A decisão encontra-se motivada, mas não justificada.

\subsection{Quinto princípio: o direito fundamental a uma resposta constitucionalmente adequada}

Depois de tudo o que já se disse nos itens anteriores, não resta outra conclusão a ser adotada senão a de que a decisão do Supremo Tribunal Federal viola o direito a uma resposta constitucionalmente adequada.

De fato, se o direito a uma resposta constitucionalmente adequada é, segundo Streck (2014a, p. 617), uma consequência da conjugação 
dos quatro princípios anteriores, vale dizer, da preservação da autonomia do direito, da repressão à discricionariedade, com a abolição de qualquer atitude arbitrária, do respeito à coerência e à integridade do direito, tomando-se por ponto de partida uma fundamentação detalhada, resta claro que, no que se refere ao novo entendimento do Supremo Tribunal Federal sobre a presunção de inocência, não houve uma resposta constitucionalmente adequada.

O princípio da presunção de inocência, como concebido pelo constituinte e inserto no artigo $5^{\circ}$., inciso LVII da Constituição da República, foi claramente violado pela decisão do Supremo Tribunal Federal, o que é por demais grave, já que a violação de um princípio implica na ruptura da própria constituição, acarretando, assim, uma inconstitucionalidade muito mais grave do que nas hipóteses em que há a violação de uma regra jurídica (STRECK, 2014b, p. 347).

\section{CONSIDERAÇões Finais}

$\mathrm{Na}$ abordagem do presente trabalho, procuramos analisar o novel posicionamento do Supremo Tribunal Federal a respeito da presunção de inocência à luz da teoria da decisão judicial formulada por Lenio Luiz Streck, suscitando a reflexão crítica a respeito da necessidade de o Poder Judiciário construir decisões constitucionalmente adequadas, ou seja, que observem, sobretudo, as balizas colocadas pelo texto da Constituição, respeitando a legislação produzida de forma democrática.

O princípio da presunção de inocência inserto no artigo $5^{\circ}$., inciso LVII, da Constituição da República de 1988, constitui-se em importante garantia constitucional de não culpabilidade no âmago do Estado Democrático de Direito, e tem na sua origem uma valoração que não pode ser desprezada, qual seja, preservar a liberdade frente aos abusos e arbitrariedades do Estado em promover a antecipação da pena antes de uma decisão condenatória definitiva.

Assim, no atual contexto histórico, em que temos observado perplexos decisões importantes do Supremo Tribunal Federal marcadas por impulsos decorrentes de variáveis morais e políticas que encontram per- 
meabilidade na opinião pública e na visão dos grandes meios de comunicação de massa, é preciso trazer à baila uma teoria do direito que se debruce sobre o ato decisório, de modo a acentuar que a decisão judicial em um Estado Democrático de Direito não pode ceder às tentações da discricionariedade e do subjetivismo do julgador, seja a que pretexto for.

Nesse compasso, a concepção de Lenio Streck a respeito de uma teoria da decisão judicial, com ênfase num conjunto de princípios conformadores do agir concretizador da Constituição, traduz-se em contribuição das mais relevantes para o cotejo do recente entendimento do Supremo Tribunal Federal acerca da presunção de inocência, de modo a aferirmos se tal posicionamento está ou não em harmonia com o direito fundamental a uma resposta constitucionalmente adequada.

Destarte, a decisão do Supremo Tribunal Federal não encontra ressonância na teoria da Decisão judicial proposta por Streck, na medida em que não passa pelo filtro hermenêutico realizado à luz da conjugação dos princípios da preservação da autonomia do direito; do controle hermenêutico da interpretação constitucional; do efetivo respeito à integridade e à coerência do direito; do dever de fundamentar as decisões.

$\mathrm{O}$ direito fundamental a uma resposta constitucionalmente adequada pressupõe a confluência dos demais princípios, ora referenciados, pois a decisão/resposta estará adequada se for respeitada a autonomia do direito, produzido democraticamente, afastada a discricionariedade e os subjetivismos, respeitada a coerência e integridade do direito, evitando casuísmos, e havendo uma detalhada fundamentação (STRECK, 2014a, p. 617).

Não há como olvidar que o direito fundamental a uma resposta constitucionalmente adequada harmoniza-se não somente com a garantia que todos devem ter de que suas demandas sejam julgadas conforme a Constituição, mas também com a necessidade de segurança jurídica e de segurança do próprio Estado Democrático de Direito, porque latente é o dever de se respeitar e observar a legislação produzida de forma democrática.

Desse modo, mitigar o princípio da presunção de inocência, como fez o Supremo Tribunal Federal, além de significar a produção de de- 
cisão eivada de ilegitimidade, representa uma erosão do próprio texto da Constituição da República, que, por óbvio, não se traduz em uma decisão constitucionalmente adequada.

\section{REFERÊNCIAS}

ARAÚJO, Luiz Alberto David; JÚNIOR, Vidal Serrano Nunes. Curso de Direito Constitucional, 12. ed. São Paulo: Saraiva, 2008.

BRASIL. Supremo Tribunal Federal. Primeira turma. Habeas Corpus n. 71.7233/SP. Rel. Min. Ilmar Galvão. Brasília, 14 de março de 1995. Disponível em: http://redir.stf.jus.br/paginadorpub/paginador.jsp?docTP=AC\&docID=73289. Acesso em: 21/02/2017.

BRASIL. Supremo Tribunal Federal. Tribunal Pleno. Arguição de Descumprimento de Preceito Fundamental $\mathbf{n}^{0}$. 144. Rel. Min. Celso de Mello. Brasília, 6 de agosto de 2008. Disponível em: http://redir.stf.jus.br/paginadorpub/paginador.jsp?docTP=AC\&docID=608506. Acesso em: 21 de fevereiro de 2017.

BRASIL. Supremo Tribunal Federal. Tribunal Pleno. Habeas Corpus 84.0787/MG. Paciente: Omar Coelho Vitor. Relator: Ministro Eros Grau. Brasília, 5 de fevereiro de 2009.

Disponívelemhttp://http://redir.stf.jus.br/paginadorpub/paginador.jsp?docTP= AC\&docID=608531. Acesso em: 21 de fevereiro de 2017.

BRASIL. Supremo Tribunal Federal. Tribunal Pleno. Habeas Corpus $n^{\circ}$ 126.292/SP. Paciente: Márcio Rodrigues Dantas. Relator: Ministro Teori Zavascki. Brasília, 17 de fevereiro de 2016. Disponível em http://redir.stf.jus.br/ paginadorpub/paginador.jsp?docTP=TP\&docID=10964246. Acesso em: $21 \mathrm{de}$ fevereiro de 2017.

FERNANDES, Bernardo Gonçalves. Curso de Direito Constitucional, 4. ed. Salvador: JusPodvim, 2012.

FERRAJOLI, Luigi. Direito e Razão: teoria do garantismo penal. São Paulo: Revista dos Tribunais, 2002. 
GIACOMOLLI, José Nereu. Comentário ao art. $\mathbf{5}^{\circ}$., LVII. In: CANOTILHO, J. J. Gomes; Mendes, Gilmar F.; SARLET, Ingo W.; . (Coords). Comentários à Constituição do Brasil. São Paulo: Saraiva/Almedina, 2013, p. 440-445.

MARCONI, Marina de Andrade; LAKATOS, Eva Maria. Metodologia científica, 3. ed. São Paulo: Atlas, 2000.

MENDES, Gilmar Ferreira; COELHO, Inocêncio Mártires; BRANCO, Paulo Gustavo Gonet. Curso de Direito Constitucional. São Paulo: Saraiva, 2007.

SIMIONI, Rafael Lazzaroto. Curso de hermenêutica jurídica contemporânea: do positivismo clássico ao pós-positivismo jurídico. Curitiba: Juruá, 2014.

STRECK, Lenio Luiz. Hermenêutica jurídica e(m) crise: uma exploração hermenêutica da construção do direito, 11. ed. Porto Alegre: Editora Livraria do Advogado, 2014b.

STRECK, Lenio Luiz. Verdade e consenso: constituição, hermenêutica e teorias discursivas, 5. ed. São Paulo: Saraiva, 2014a.

TAVARES, André Ramos. Curso de Direito Constitucional, 11. ed. São Paulo: Saraiva, 2013.

\section{SOBRE OS AUTORES}

\section{Júlio Cesar Muniz}

Graduado em Direito pelo Centro Regional Universitário de Espírito Santo do Pinhal e em História pela Universidade de Uberaba. Especialista em Direito Processual Civil pela Pontifícia Universidade Católica de Campinas e também em Direito Empresarial pelo Centro Regional Universitário de Espírito Santo do Pinhal. Mestrando em Constitucionalismo e Democracia pela Faculdade de Direito do Sul de Minas. Atualmente, é professor universitário do Centro Regional Universitário de Espírito Santo do Pinhal e do Instituto de Ensino Superior de Itapira, exerce a função de Assessor de Juiz - Tribunal de Justiça do Estado de Minas Gerais e professor de história da Sociedade de Educação e Cultura. Tem experiência na área de Direito, com ênfase em Direito Constitu- 
cional, Processual Civil e Direito de Família.

CV: http://lattes.cnpq.br/4069066950707704

munizjc@ig.com.br

\section{Cláudia Mansani Queda de Toledo}

Possui Mestrado em Direito das Relações Sociais pela Pontifícia Universidade Católica de São Paulo (2008). Doutora em Direito Constitucional na linha de pesquisa Sistema Constitucional de Garantia de Direitos pela Instituição Toledo de Ensino, Bauru/SP (2012). É docente nas áreas de Direito Constitucional, com ênfase na área de Direito à Educação, Direitos Humanos e Metodologia da Pesquisa Científica e Metodologia do Ensino Superior. Atualmente, é sócia e coordenadora do escritório Toledo e Mesquita Sociedade de Advogados, em Bauru e São Paulo e docente nos cursos de graduação, pós-graduação lato e stricto sensu da FDSM - Faculdade de Direito do Sul de Minas, desde 2013. Professora da disciplina Processo Constitucional no curso de direito da Instituição Toledo de Ensino. É Reitora do Centro Universitário de Bauru.

CV: http://lattes.cnpq.br/5995072476063036

quedatoledo@uol.com.br

Submetido em: 2-5-2018

Aceito em: 3-5-2018 